Canadian Science Publishing

Canadian Journal of Microbiology Revue canadienne de de microbiologie

\title{
Biodegradation of waste greases and biochemical properties of a novel lipase from Pseudomonas synxantha PS1
}

\begin{tabular}{|c|c|}
\hline Journal: & Canadian Journal of Microbiology \\
\hline Manuscript ID & cjm-2015-0641.R2 \\
\hline Manuscript Type: & Article \\
\hline Date Submitted by the Author: & 04-Mar-2016 \\
\hline Complete List of Authors: & $\begin{array}{l}\text { Cai, Xianghai; State Key Laboratory of Bioreactor Engineering, Newworld } \\
\text { Institute of Biotechnology } \\
\text { Chen, Siqi; State Key Laboratory of Bioreactor Engineering, Newworld } \\
\text { Institute of Biotechnology } \\
\text { Yang, Hong; State Key Laboratory of Bioreactor Engineering, Newworld } \\
\text { Institute of Biotechnology } \\
\text { Wang, Wei; State Key Laboratory of Bioreactor Engineering, Newworld } \\
\text { Institute of Biotechnology } \\
\text { Lin, Lin; Research Laboratory for Functional Nanomaterial, National } \\
\text { Engineering Research Center for Nanotechnology } \\
\text { Shen, Yaling; State Key Laboratory of Bioreactor Engineering, Newworld } \\
\text { Institute of Biotechnology } \\
\text { Wei, Wei; State Key Laboratory of Bioreactor Engineering, East China } \\
\text { University of Science and Technology } \\
\text { Wei, Dongzhi; State Key Laboratory of Bioreactor Engineering, Newworld } \\
\text { Institute of Biotechnology }\end{array}$ \\
\hline Keyword: & Characterization, Pseudomonas synxantha, Lipase, Biodegradation \\
\hline
\end{tabular}

\section{SCHOLARONE"}

Manuscripts 


\section{Biodegradation of waste greases and biochemical properties of a novel lipase}

2 from Pseudomonas synxantha PS1

3

4

5

6

7

8

9

Xianghai Cai ${ }^{1}$, Siqi Chen ${ }^{1}$, Hong Yang ${ }^{1}$, Wei Wang ${ }^{1}$, Lin $_{\text {Lin }}^{2}$, Yaling Shen ${ }^{1}$, Wei Wei ${ }^{1 *}$, Dong-zhi Wei ${ }^{1}$

${ }^{1}$ State Key Laboratory of Bioreactor Engineering, Newworld Institute of Biotechnology, East China University of Science and

Technology, Shanghai 200237, People's Republic of China

${ }^{2}$ Research Laboratory for Functional Nanomaterial, National Engineering Research Center for Nanotechnology, Shanghai 200241,

People's Republic of China

Xianghai Cai: caixianghai2008@163.com

Siqi Chen: 1156851922@qq.com

Hong Yang: yh890614@163.com

Wei Wang: wadexp@163.com

Lin Lin: linlin21023@163.com

Yaling Shen: ylshen@ecust.edu.cn

Dong-zhi Wei: dzhwei@ecust.edu.cn

\section{* Corresponding author:}

Wei Wei: Newworld Institute of Biotechnology, State Key Laboratory of Bioreactor Engineering, East China University of Science and Technology, 130 Meilong Road, 200237, Shanghai, China. Tel: +86-21-64251803, Fax: +86-21-64251803, Email: 

49

\section{Abstract}

A lipase-producing bacterial strain was isolated from oilwell produced water in Shengli oilfield (Shandong province, China) and identified as Pseudomonas synxantha by 16S rDNA sequence analysis (named Pseudomonas synxantha PS1). The strain PS1 showed maximum lipase activity of $10.8 \mathrm{U} / \mathrm{ml}$ after cultured for $48 \mathrm{~h}$ at $30^{\circ} \mathrm{C}$, with lactose $(4 \mathrm{~g} / \mathrm{l})$ as carbon source, tryptone $(8 \mathrm{~g} / 1)$ as nitrogen source, olive oil $(0.5 \%, \mathrm{v} / \mathrm{v})$ as inductor and the initial $\mathrm{pH}$ 8.0. Meanwhile, the lipase gene from Pseudomonas synxantha PS1 was cloned and expressed in Escherichia coli BL21 with the vector pET28a. The novel gene (lipPS1) has an open reading frame of 1425 bp, and encodes a 474-amino-acid lipase (LipPS1) sharing the most identity 87\% to the lipase in Pseudomonas fluorescens. LipPS1 preferably acted on substrates with a long chain $(\mathrm{C} 10-\mathrm{C} 18)$ of fatty acids. The optimum $\mathrm{pH}$ and temperature of the recombinant enzyme were 8.0 and $40^{\circ} \mathrm{C}$ towards the optimum substrate p-nitrophenyl palmitate respectively. The LipPS1 showed remarkable stability under alkaline conditions and was stable at $\mathrm{pH} 7.0-10.0$ (retaining more than $60 \%$ activity). From the organic solvents tests, the lipase was activated by $15 \%$ (v/v) methanol (112\%), ethanol (127\%) and n-butyl alcohol (116\%). LipPS1 presented strong biodegradability of waste grease, $93 \%$ waste grease was hydrolyzed into fatty acid after $12 \mathrm{~h}$ at $30^{\circ} \mathrm{C}$. This is the first report of the lipase activity and lipase gene obtained from Pseudomonas synxantha (including wild strain and recombinant strain) and the recombinant LipPS1 with the detailed enzymatic properties. Also the preliminary study of the waste greases biodegradability shows the potential value in industry applications.

\section{Keywords: Characterization; Pseudomonas synxantha; Lipase; Biodegradation}

4

45

\section{(6)}

\section{(} 50 st 


\section{Introduction}

Lipases (triacylglycerol acylhydrolase, EC 3.1.1.3) are a class of enzymes that can catalyze the hydrolysis of long-chain triacylglycerols into fatty acids and glycerol. They are widely distributed in bacteria, yeasts, fungi, plants and animals (Pahoja and Sethar 2002). The lipases are widely used in various industries like food, dairy, chemical, textile, pharmaceutical, cosmetic, detergent production, and especially in biodiesel production and synthesis of new polymeric materials (Gupta et al. 2004). As containing so many applications, novel enzyme with distinct features such as thermostable, alkaline, high activities and stabilities in organic solvents is of interest for industrial applications (Fang et al. 2006).

Lipases from Pseudomonas species have attracted more attention since they have the potential application in detergent and chemistry industries. Although many Pseudomonas lipases genes from Pseudomonas cepacia (Dhake et al. 2013), Pseudomonas aeruginosa (Bose and Keharia 2013; Grbave`ic et al. 2015), Pseudomonas resinovorans (Lee et al. 2012), Pseudomonas stutzeri (Maraite et al. 2013) and pseudomonas fluorescence (Hakiminia et al. 2013) have been cloned and sequenced, there is no report of $P$. synxantha lipase including wild strain lipase activity, lipase gene cloning from $P$. synxantha and recombinant strain. Recently, the increased waste oils and greases in waste water polluted the environment seriously (Kumar et al. 2012). Biodegradation and synthesis of biodiesel, two main waste grease processing solutions were recognized so far. Waste greases used for biodiesel production attracted people's attention and has been studied extensively (Tan et al. 2010; Luna et al. 2014). However, oils used for biodiesel production required pure enough. In other words, oils for transesterification could not contain water. But waste greases in these environments like rivers, lakes, ocean and sewer, were not suitable for synthesis of biodiesel. One reason was oil content was low, and the other was oil-water separation needing a large economic expenditure. So biodegradation became the effective treatment method of waste oil in the environment (Sangeetha et al. 2011). Lipase provided an excellent hydrolysis activity towards long-chain waste greases and played an important role in promoting the degradation of waste greases.

Previously, we have obtained a lipolytic strain which was identified as Pseudomonas synxantha (named Pseudomonas synxantha PS1). In this study, a novel lipase gene (lipPS1) was obtained from P. synxantha and the in-vivo functional expression of the lipPS1 was successfully achieved. The enzyme characterizations including the enzyme activity/stability, optimum temperature, 
optimum $\mathrm{pH}$ and conditions for lipase production were also described. This first report lipase from Pseudomonas synxantha would contribute to Pseudomonas synxantha strain research significantly. As showing high biodegradability towards waste greases, this alkaline-adapted lipase (LipPS1) showed potential value in industrial applications according to the enzyme characterizations especially in the detergent and environment industry.

\section{Materials and Methods}

\section{Chemicals, strain screening and culture conditions}

PrimeSTAR HS DNA Polymerase, LA Taq, T4 DNA ligase, DNA marker and restriction enzymes were purchased from TaKaRa Biotechnology Corporation (Otsu, Japan). Protein marker was purchased from MBI Fermentas (Vilnius, Lithuania). Isopropyl- $\beta$-D-thiogalactopyranoside (IPTG), ampicillin and kanamycin were purchased from Amresco (Shanghai Genebase Co., Ltd, China). DNA Mini kit and Plasmid Mini Prepare kit were purchased from Axygen Biosciences (Union City, CA, USA). Escherichia coli DH5 $\alpha$ (Invitrogen) and plasmid pMD19-T (TaKaRa) were used for gene cloning and sequencing. Plasmid pET-28a (Novagen) was the vector used to construct the protein expression plasmid in E. coli BL21 (DE3). The substrates p-nitrophenyl esters were bought from Sigma. Yeast extract and tryptone were obtained from Shanghai Sangon Biotechnology Co. Ltd (Shanghai, China). All other analytical chemicals were purchased at local markets.

In this work, enrichment culture technique was applied. LB medium added with $1 \%$ olive oil emulsion was used to isolate potential bacterial strains. One $\mathrm{ml}$ sample (oil well produced water) was added to a flask with $100 \mathrm{ml}$ sterile distilled water. With activating on a rotary for $40 \mathrm{~min}, 0.1 \mathrm{ml}$ activation culture broth was inoculated into $100 \mathrm{ml}$ enriched medium. Then the medium was shaken at $120 \mathrm{rpm}, 30^{\circ} \mathrm{C}$ for $48 \mathrm{~h}$. After several rounds of enrichment, inocula was serially diluted and plated onto Rhodamine B agar plates (Cai et al. 2014). The microbes showing obviously hydrolysis circle were isolated, purified and transferred to maintenance slants. The strain (PS1) showing the highest ratios of hydrolysis circles was selected and identified by 16S rDNA (GenBank accession numbers: KM232508) sequence analysis. Multiple sequence alignments were performed using DNAMAN and CLUSTAL

W. The unrooted phylogenetic tree of $16 \mathrm{~S}$ rDNA comparison was constructed using the MEGA program. The gene of 16S rDNA was amplified and sequenced using primers universal for the majority of prokaryotes (forward primer 5'-CCTACGGGAGGCAGCAG-3', 

reverse primer 5'-ACGGGCGGTGTGTAC-3').

\section{Optimization of culture medium composition}

In an effort to optimize the medium components, the single-factor experiments method of adding different carbon sources, nitrogen sources and greases in P. synxantha PS1 culture medium was used. Various carbon sources, nitrogen sources and greases which were considered to increase extracellular lipase production by some microorganisms were used for lipase production (Rajendran and Thangavelu 2007). Basal medium was composed of $1.0 \mathrm{~g} / 1 \mathrm{NaCl}, 0.5 \mathrm{~g} / 1 \mathrm{NaH}_{2} \mathrm{PO}_{4}, 1.0 \mathrm{~g} / 1 \mathrm{NH}_{4} \mathrm{NO}_{3}$ and $0.5 \mathrm{~g} / 1 \mathrm{KH}_{2} \mathrm{PO}_{4}$.

The experiment was performed to verify the statistical results of optimized value of different factors and the medium was prepared with these factors as constituents. The effects of the different carbon sources were studied as follows $\left(4 \mathrm{~g}^{-1}\right)$ : lactose, maltose, starch, sucrose and glucose. The effects of the different nitrogen sources were studied as follows $\left(8 \mathrm{~g} \mathrm{l}^{-1}\right)$ casein, tryptone, yeast extract, soybean flour and peanut powder. To examine the effect of greases, five different greases $0.5 \%$ (v/v) (sesame oil, coconut oil, sunflower oil, palm oil and olive oil) were compared in the lipase production. The P. synxantha PS1 was cultivated in $250 \mathrm{ml}$ flasks containing $50 \mathrm{ml}$ of culture medium at $200 \mathrm{rpm}$ and $30^{\circ} \mathrm{C}$. After incubation the content of flask was centrifuged at $5000 \mathrm{~g}$ and the supernatant was used as crude enzyme extract(Joshi et al. 2006).

\section{Gene cloning and lipPS1 analysis}

Based on the information of Pseudomonas spp. lipases in GenBank, degenerate primers (forward primer DP-lipPS1-F: 5'-TCSGGVCCTCGGGAAA-3', DP-lipPS1-R: 5'-GTRTYGCCCTTRTGCG-3') for the lipase gene sequence were designed. According to NCBI search, the following gene sequences of predicted lipase from Pseudomonas spp. were analyzed to design degenerate primers: P. fluorescens LBUM223 (CP011117), Pseudomonas sp. KB700A (AB063391), Pseudomonas simiae WCS417 (CP007637), Pseudomonas poae RE1-1-14 (CP004045), Pseudomonas fluorescens PCL1751 (CP010896). The PCR amplification was enforced with thermostable polymerase LA Taq in the GC buffer. The scheme of amplification included 30 cycles with the following conditions: DNA denaturation at $94^{\circ} \mathrm{C}$ for $30 \mathrm{~s}$, annealing of primers at $52^{\circ} \mathrm{C}$ for $30 \mathrm{~s}$, and elongation at $72^{\circ} \mathrm{C}$ for $40 \mathrm{~s}$. The targeted fragment with approximate length as we anticipated was sequenced in two directions in BGI (China).

Then, genomic walking and nested PCR were employed to obtain the complete lipase sequence (CDS sequence) using TaKaRa 
121

122

123

124

125

126

127

128

129

130

LA PCR ${ }^{\mathrm{TM}}$ in vitro Cloning Kit (TaKaRa). Target DNA upstream and downstream sequence of lipase was specifically amplified.

Through sequences splicing and ORF sequences searching (NCBI ORF Finder tool http://www.ncbi.nlm.nih.gov/gorf/gorf.html), the

complete lipase sequence (lipPS1) was obtained and primers LipPS1-F/LipPS1-R (forward primer lipPS1-F:

5'-CGGAATTCATGGGTGTGTTTGACTA-3', reverse primer lipPS1-R: 5'- CCAAGCTTTTAACTGATGACAATCCCC-3',

underlined nucleotides indicate restriction enzyme sites BamHI/Xhol) for the complete lipase sequence were designed. The complete

lipPS1 sequence (Genbank accession number: KT313129) was amplified by PCR with the following scheme: initial denaturation at

$94^{\circ} \mathrm{C}$ for $5 \mathrm{~min}, 30$ cycles of $94^{\circ} \mathrm{C}$ for $1 \mathrm{~min}, 55^{\circ} \mathrm{C}$ for $1 \mathrm{~min}, 72^{\circ} \mathrm{C}$ for $2 \mathrm{~min}$, and a final extension of $8 \mathrm{~min}$ at $72^{\circ} \mathrm{C}$. The PCR

products were cloned into pMD-19T simple vector after recovering by DNA gel extraction kit (Axygen, China), and then transferred

into E. coli DH5 $\alpha$. The open reading frame (ORF) was predicted using the NCBI ORF Finder tool

(http://www.ncbi.nlm.nih.gov/gorf/gorf.html). The signal peptide was predicted by the SignalP 4.0 server

(http://www.cbs.dtu.dk/services/SignalP/). Enzyme Mw and pI were predicted using the ExPASy proteomic server program Compute

$\mathrm{pI} / \mathrm{Mw}$ (http://web.expasy.org/compute_pi/). Meanwhile, as no report of $P$. synxantha lipase in previous research, the three-dimensional structure of LipPS1 was predicted by the SWISS-MODEL server and the protein structure was viewed by PdbViewer.

Functional expression of lipase in $E$. coli

Plasmid pET-28a was used for gene expression in E. coli. After digestion by BamHI/XhoI, the lipPS1 gene was reclaimed and connected with pET-28a vector, which were digested by the same restriction endonuclease. The recombinant plasmid pET-28-lipPS1 was transformed into E. coli BL21 (DE3). The recombinant lipase strain was incubated in 5 ml Luria-Bertani (LB) medium containing kanamycin $\left(50 \mu \mathrm{g} \mathrm{ml}^{-1}\right)$ at $37^{\circ} \mathrm{C}$ for $12 \mathrm{~h}$ and then transferred into $50 \mathrm{ml} \mathrm{LB}$ medium for propagation. IPTG $(0.1 \mathrm{mM})$ was

added to the medium until the absorbance at $600 \mathrm{~nm}$ was 0.6 . With the cultivation condition at $20^{\circ} \mathrm{C}$ for $18 \mathrm{~h}$, the crude enzyme was collected by ultrasonic broken after the strains were harvested by centrifugation (12, $000 \times \mathrm{g}, 10 \mathrm{~min}$ ) (Cai et al. 2014).

\section{Purification of recombinant lipase and SDS-PAGE analysis}

After induction by IPTG, cells were separated by centrifugation, dispersed in sodium dodecyl sulfate-polyacrylamide gel 
144

145

electrophoresis (SDS-PAGE) sample buffer and heated to $100^{\circ} \mathrm{C}$. Finally, proteins were separated by SDS-PAGE (12.5\%

acrylamide/bis-acrylamide) and stained with coomassie blue.

The previous articles described the methods for heterologous protein expression and Ni-NTA purification procedures in our group. After lysed by sonication, the crude enzyme was passed through a $0.22 \mu \mathrm{m}$ filter and then applied to a Ni-NTA sperflow column (1 ml, Qiagen). After equilibrated with the lysis buffer (NPI 10: $50 \mathrm{mM} \mathrm{NaH}_{2} \mathrm{PO}_{4}, 300 \mathrm{mM} \mathrm{NaCl}, 10 \mathrm{mM}$ imidazole, $\mathrm{pH}$ 8.0), the column was subsequently washed with $10 \mathrm{ml}$ of wash buffer (NPI 20: $50 \mathrm{mM} \mathrm{NaH}_{2} \mathrm{PO}_{4}, 300 \mathrm{mM} \mathrm{NaCl}, 20 \mathrm{mM}$ imidazole, $\mathrm{pH}$ 8.0) to remove the impurity protein. The fusion protein (His-tagged LipPS1) was eluted with a linear gradient of washing buffer (from NPI 50 to NPI 250). The eluted protein was desalted and concentrated by ultrafiltration using a $50 \mathrm{ml}$ Amicon Ultra Centrifugal Filter Device with a molecular weight cut-off of $10 \mathrm{kDa}$ (Millipore, USA). The purified enzyme was resuspended in sodium phosphate buffer ( $\mathrm{pH} 7.0$ ) containing $20 \%$ glycerol and stored at $-40^{\circ} \mathrm{C}$. The crude extract and the pure enzyme were analyzed by SDS-PAGE. All purification steps were carried out at $4^{\circ} \mathrm{C}$. Protein concentration was determined by the Bradford method with bovine serum albumin (BSA) as the standard.

\section{Assay of lipase activity}

Enzyme activities of LipPS1 solution were assayed by measuring the absorbance at $405 \mathrm{~nm}$ of liberated p-nitrophenol. The reaction mixture $(0.5 \mathrm{ml})$ contained $50 \mu \mathrm{l}$ of 4-nitrophenyl palmitate solution (final concentration of $25 \mathrm{mM}$ in the solution of isopropanol and dimethyl sulfoxide with volume ratio $3: 1)$ as the substrate, $440 \mu$ l of lipase assay buffer $(50 \mathrm{mM} \mathrm{Glycine- \textrm {NaOH }}$ buffer, $\mathrm{pH}$ 9) and $10 \mu \mathrm{l}$ of appropriately diluted enzyme sample. $1 \mathrm{U}$ is defined as the amount of enzyme releasing $1 \mu \mathrm{mol}$ p-nitrophenol per min under the assay conditions.

\section{Characterization of lipase}

The lipase activity of the enzyme sample without any processing was considered as control (100\%). Each experiment was repeated three times and each experiment included three replicates. The average values of triplicate measurements were used as each activity value. All values are means \pm SD from three independent experiments (repeats with $\mathrm{SD}$ of $\leq 5 \%$ ). The ability of the purified enzyme to hydrolyze various substrates p-nitrophenyl esters (C2-C18) was examined at $40^{\circ} \mathrm{C}$ and $\mathrm{pH}$ 8.0. 
The $\mathrm{pH}$ optimum for the enzyme activity was studied over a range from $\mathrm{pH} 2-10$ for $5 \mathrm{~min}\left(40^{\circ} \mathrm{C}\right)$. The $\mathrm{pH}$ stability of the enzyme was determined by incubating the enzyme in different buffers for $12 \mathrm{~h}$ and incubated at $40^{\circ} \mathrm{C}$. The following buffer systems were used: $\mathrm{pH}$ 2.0-3.0 with $50 \mathrm{mM}$ glycine- $\mathrm{HCl}, \mathrm{pH} 4.0-5.0$ with $100 \mathrm{mM}$ citric acid-sodium citrate, $\mathrm{pH}$ 6.0-7.0 with $200 \mathrm{mM}$ sodium phosphate, $\mathrm{pH} 8.0$ with $50 \mathrm{mM}$ Tris- $\mathrm{HCl}, 9.0-10.0$ with $50 \mathrm{mM}$ glycine- $\mathrm{NaOH}$ and $\mathrm{pH} 11.0$ with 50 mM sodium hydrogen phosphate- $\mathrm{NaOH}$. The temperature optimum for the enzyme activity was assayed at $10-50^{\circ} \mathrm{C}(\mathrm{pH} 9.0)$. The thermal stability of LipPS1 was evaluated by assaying its residual activity after incubation of the enzyme at various temperatures for $12 \mathrm{~h}$ in sodium phosphate buffer (pH9.0). The effects of metal ions on the lipase activity were determined with various metal ions (1 and $8 \mathrm{mM})$ such as $\mathrm{Fe}^{2+}, \mathrm{Mg}^{2+}, \mathrm{Ca}^{2+}, \mathrm{Cu}^{2+}, \mathrm{Zn}^{2+}, \mathrm{Co}^{2+}, \mathrm{Ni}^{2+}$ and $\mathrm{Mn}^{2+}$ (pH 9.0). Meanwhile, effects of surfactants (Tween 20, Tween 80, TritonX-100, sodium dodecyl sulfate (SDS), EDTA and DTT at the concentration of $1.0 \mathrm{mM}$ ) and various organic solvents (Methanol, Ethanol, Acetonitrile, Benzene, n-hexane, Chloroform, DMSO, Acetone, Are propanol and Isopropanol) (15\% (v/v) and 25\% (v/v)) were measured using the spectrophotometric assay as above. The reaction mixtures containing the enzyme sample were incubated at $40^{\circ} \mathrm{C}$ for $60 \mathrm{~min}$ in $50 \mathrm{mM}$ glycine- $\mathrm{NaOH}$ buffer, $\mathrm{pH}$ 9.0. The enzyme sample without any additives was considered as control (100\%).

\section{Biodegradation of waste grease}

The waste greases contains plant oil and animal oil from the kitchen liquid waste was applied in this study. The reaction mixture containing $5.0 \mathrm{ml}$ liquid waste (containing $150 \mathrm{mg}$ waste oil) and $3.0 \mathrm{mg}$ purified enzyme. After shaking with $150 \mathrm{rpm}$ at a certain temperature for $15 \mathrm{~h}$, fatty acid products were detected in the samples. Liquid waste without enzyme was as control. To confirm a suitable temperature for the lipase-catalyzed biodegradation of waste grease, a series of temperature $\left(20^{\circ} \mathrm{C}, 30^{\circ} \mathrm{C}, 40^{\circ} \mathrm{C}\right.$ and $50^{\circ} \mathrm{C}$ ) were tested.

\section{Results}

\section{Identification of bacteria and phenotypic characterization}

With the progress of the above research, 1046 bp of 16S rDNA (GenBank accession numbers: KM232508) fragment in strain PS1 was finally obtained. Based on the 16S rRNA analyses, strain PS1 was identified as Pseudomonas spp. In the phylogenetic tree, 
190

191

192

193

the 16S rDNA sequence of strain PS1 displayed the similarity of $97-99 \%$ to the other Pseudomonas sp. (including $P$. cedrina, $P$. azotoformans, $P$. fluorescens, $P$. gessardii, $P$. reactans and $P$. synxantha) (Fig. 1a) and showed the most homologous with $P$. synxantha. The results of $16 \mathrm{~S}$ rDNA analysis and lipase gene analysis allowed the strain PS1 to be ascribed to the species $P$. synxantha. Other analyses were done to futher support the isolate as a $P$. synxantha strain. In other research, we cloned a thermostable carboxylesterase (EstPS1) from Pseudomonas synxantha PS1. The GenBank accession number for the Pseudomonas synxantha PS1 carboxylesterase gene is KT070707. Homology analysis revealed that EstPS1 in Pseudomonas synxantha shared the most identity $98 \%$ with the whole-genome shotgun contigs (WGS) of $P$. synxantha BG33R, $88 \%$ with carboxylesterase EstA in Pseudomonas fluorescens A506 (GI: 387159426) and 84\% identical to the carboxylesterase in Pseudomonas poae RE*1-1-14 (GI: 445198867). This provided the further evidence that the new selected strain belong to $P$. synxantha. Transparent zone method proved that the strain could produce lipase, for an obvious circle was detected on the screening plate (Fig. 1b). Meanwhile, as no report of this lipase in previous research, phenotype info of P. synxantha PS1 was shown in Fig. 1c.

\section{Nutritional factors and environmental conditions on lipase production}

In this experiment, lactose was found to be the superior carbon source (lipase activity $6.53 \pm 0.32 \mathrm{U} \mathrm{ml}^{-1}$ ). Except starch, remarkable lipase activity was obtained with maltose, sucrose and glucose. Many inorganic nitrogen sources had an effect on lipase production (Dutta and Ray 2009), and we also found nitrogen sources exhibited high enhancement on lipase production in this study. Nitrogen sources like soybean flour and peanut powder exhibited high lipase production of $5.83 \pm 0.78$ and $5.64 \pm 0.6 \mathrm{U} \mathrm{ml}^{-1}$ respectively (Fig. 2a). Tryptone led to the highest activity of $7.8 \pm 0.52 \mathrm{U} \mathrm{ml}^{-1}$, and casein or yeast extract was found to be unsuitable as nitrogen source in this study.

Lipase production was carried out using different grease as induction nutrition with lactose as carbon source and tryptone as nitrogen source, other conditions remaining the same. Lipase inductor and time course of fermentation had a significant effect on maximum production of lipase (Lotti et al. 2001; Kulkarni and Gadre 2002). Maximum lipase activity $10.8 \pm 0.52 \mathrm{U}^{-1} \mathrm{was}^{-}$ observed at $48 \mathrm{~h}$ of olive oil $(0.5 \%, \mathrm{v} / \mathrm{v})$ (Fig. 2b). Palm oil, sunflower oil, coconut oil and sesame oil led to almost the same lipase production at $48 \mathrm{~h}$, they were found to be $9.16 \pm 0.35,8.98 \pm 0.47,8.65 \pm 0.29$ and $8.42 \pm 0.55 \mathrm{U} \mathrm{ml}^{-1}$. In conclusion, the strain PS1 
213

214

215

216

217

218

219

220

221

222

showed maximum lipase activity of $10.8 \mathrm{U} / \mathrm{ml}$ after cultured for $48 \mathrm{~h}$ at $30^{\circ} \mathrm{C}$, with lactose $(4 \mathrm{~g} / \mathrm{l})$ as carbon source, tryptone $(8 \mathrm{~g} / \mathrm{l})$ as nitrogen source, olive oil $(0.5 \%, \mathrm{v} / \mathrm{v})$ as inductor and the initial $\mathrm{pH} 8.0$.

\section{Homology analysis of LipPS1}

A 650-bp fragment was amplified from the genomic DNA of $P$. synxantha PS1 by using the degenerate primers DP-lipPS1-F/DP-lipPS1-R (Fig. 1d). Sequence analysis indicated that it shared the most identity with a lipase from P. fluorescens GI: 489309678. By nested-PCR and chromosome walking, about 2 kb DNA fragment was cloned and sequenced, which contains a full-length ORF consisting of $1425 \mathrm{bp}$. The GenBank accession number of lipPS1 is KT313129. Sequence analysis revealed that the sequence of the lipPS1 ORF encoding a polypeptide of 474 amino acids uses ATG as the start codon. The $\mathrm{G}+\mathrm{C}$ content (\%) of the lipPS1 is $59.2 \%$.

Using the neighbor-joining method (CLUSTAL W), the lipPS1 amino acid in P. synxantha PS1 was aligned with the other confirmed lipase from other Pseudomonas sp. (Fig. 3a). Homology analysis revealed that LipPS1 in P. synxantha shared the most identity $87 \%$ to the lipase in P. fluorescens GI: 489309678 (87\% to P. simiae GI: 835531504, 86\% to P. tolaasii GI:515538732, $85 \%$ to $P$. veronii GI: $817110927,51 \%$ to $P$. lundensis GI:860320366, 23\% to P. chlororaphis GI:565887480, $35 \%$ to Pseudomonas sp. WCS374, 58\% to P. moraviensis GI:566144243, 55\% to P. fuscovaginae GI:498134231, 56\% to P. kilonensis GI:802904114 and $39 \%$ to Pseudomonas sp. PH1b GI:640705641. Phylogenetic tree based on the protein sequences of LipPS1 and relating species. Bootstrap values obtained with 1000 repetitions were indicated as percentages at all branches (Fig. 3b). Also, LipPS1 contains a single catalytic domain of the alpha/beta hydrolase family and belongs to the family of triacylglycerol lipase (EC 3.1.1.3). The molecular weight of LipPS1 was estimated to be $49.8 \mathrm{kDa}$, and the pI value was calculated to be 4.60 by the ExPASy compute $\mathrm{pI} / \mathrm{Mw}$ program algorithm. Visual inspection of the alignment revealed conservation of aa in regions associated with catalysis and stabilization of the protein, e.g. the catalytic triad $\mathrm{Ser}^{207}, \mathrm{Asp}^{255}$, and $\mathrm{His}^{313}$. The conserved region, Gla-Xxx-Ser-Xxx-Gly (the feature of the lipase sequences from Pseudomonas sp.) is boxed (Angkawidjaja et al. 2007) (Fig. 3).

\section{Expression and purification of the recombinant enzyme in E. coli}

Recombinant strain (BL21-pET-28-lipPS1) was grown to saturation in LB medium supplemented with appropriate antibiotic to 
express the recombinant protein. The optimum induction temperature was $20^{\circ} \mathrm{C}$, as shown in $\mathbf{F i g}$. $\mathbf{4 a}$, the SDS-PAGE results showed that the recombinant protein appeared as the soluble protein. Through Ni-NTA purification procedures, the purified LipPS1 migrate a single band on SDS-PAGE with an apparent molecular mass of about $50 \mathrm{kDa}$, which was identical to the calculated value. The recombinant strain was spreading to the screening plate to confirm the expression, and very strong transparent circle was detected after cultured at $37^{\circ} \mathrm{C}$ for $4 \mathrm{~h}$ (Fig. $\mathbf{4 b}$ ). The purified enzyme migrated on SDS-PAGE as a single band with an apparent molecular mass of about $50.0 \mathrm{kDa}$ (Fig. 4a). The results indicated that Ni-NTA affinity chromatography was an appropriate method for this protein purification.

\section{Substrate specificity analysis}

The activities of the enzyme towards various p-nitrophenyl esters were investigated (Fig. $\mathbf{4 c}$ ). With respect to the fatty acid specificity, the enzyme exhibited high hydrolyzed activity on long chain fatty acids (C10-C18). Lipase showed highest activity towards 4-nitrophenyl palmitate among the substrates examined. The enzyme specificity towards lipids with fatty acid residues of C10-C16 chain length strongly suggest that the enzyme used in this study was a true lipase.

\section{Optimum pH and pH stability}

The LipPS1 exhibited higher activities over a pH range of 6-10, among which the highest specific enzyme activity was at $\mathrm{pH}$ 8.0 (Fig. 5a). The activity of LipPS1 decreased significantly below pH 6 and about $65 \%$ of the maximal activity at pH 6 . Stability of the lipase was investigated in buffer solutions over the $\mathrm{pH}$ range of 4-10. Fig. 5b showed that the lipase is an alkaline $\mathrm{pH}$ stability enzyme which was most stable at $\mathrm{pH} 6-10$, among which the highest stability was at $\mathrm{pH} 7$ (retaining $86 \%$ activity). This was very similar to protease-free lipase from Pseudomonas sp. (Kulkarni and Gadre 2002).

\section{Optimum temperature and thermal stability}

Over a temperature range of $20-60^{\circ} \mathrm{C}$, LipPS1 showed more than $67 \%$ of the highest activity. Among which the highest specific enzyme activity was at $40^{\circ} \mathrm{C}$ (Fig. 5c). The lipase derived from $P$. gessardii, $P$. fluorescens, $P$. fragi and $P$. mendoncina were found to be optimally active within $35-45^{\circ} \mathrm{C}$ (Ramani and Sekaran 2012). Residual activities were determined with standard assay conditions. The lipase was entirely stable at $10^{\circ} \mathrm{C}-60^{\circ} \mathrm{C}$ and more than $47 \%$ of its activity was retained after $12 \mathrm{~h}$ in $50^{\circ} \mathrm{C}(\mathbf{F i g} .5 \mathbf{d})$. 
A lipase from P. fluorescens has a similar temperature optimum and stability (Kulkarni and Gadre 2002).

\section{Stability in organic solvents and metal ions}

From the organic solvents tests, the enzyme is fairly stable in organic solvents (Table 1). Many reported lipase from Pseudomonas sp. exhibited stability in some organic solvents, such as $P$. aeruginosa CS-2 (Peng et al. 2010) and $P$. cepacia (Dhake et al. 2013). Also we found that the lipase was activated by $15 \%(\mathrm{v} / \mathrm{v})$ methanol (112\%), ethanol (127\%) and n-butyl alcohol (116\%).

Except benzene had an obvious inhibition, the other organic solvents led to slightly influence on lipase activity.

At low concentration $(2 \mathrm{mM}), \mathrm{Ca}^{2+}, \mathrm{Fe}^{2+}, \mathrm{Cu}^{2+}, \mathrm{Mn}^{2+}, \mathrm{Co}^{2+}, \mathrm{Ni}^{2+}$ and $\mathrm{Zn}^{2+}$ partly inhibited the enzyme activity (Table 2). However, at high concentration $(10 \mathrm{mM}), \mathrm{Cu}^{2+}, \mathrm{Mn}^{2+}, \mathrm{Co}^{2+}, \mathrm{Ni}^{2+}$ and $\mathrm{Zn}^{2+}$ showed significantly inhibited effects especially for $\mathrm{Mn}^{2+}$ (only $13 \%$ of the highest activity). In contrast, $\mathrm{Mg}^{2+}$ enhanced the enzyme activity of $110 \%(2 \mathrm{mM})$ and $106 \%(10 \mathrm{mM})$.

\section{Biodegradation of waste grease}

As shown in Fig. 6a, lipPS1 presented strong biodegradability of waste grease. Waste grease at the topside of the reaction mixture was hydrolyzed nearly completely. Total theoretical amount of fatty acid was defined as $100 \%$. Waste grease degradation efficiency was determined through fatty acid production rate. In biodegradation of waste oil (Fig. 6b), two influence factors of the recombinant LipPS1 on the reaction was investigated including temperature and reaction time. The results indicated that the optimal temperature of LipPS1 biodegradation reaction was $30^{\circ} \mathrm{C}$, and $93 \%$ waste grease was hydrolyzed into fatty acid. Even high temperature $\left(50^{\circ} \mathrm{C}\right)$ could accelerate the reaction rate, but the final conversion was lower. Conversion of the biodegradation at $20^{\circ} \mathrm{C}$ was $86 \%$ after $15 \mathrm{~h}$, which was higher than $83 \%$ at $50^{\circ} \mathrm{C}$ under the same condition.

\section{Nucleotide sequence accession numbers}

The GenBank accession numbers for the Pseudomonas synxantha PS1 16S rDNA gene is KM232508, and KT313129 for lipPS1 gene.

\section{Discussion}

Lipase is an important enzyme which was used especially in lipid hydrolysis, biodiesel production and synthesis of new 
282

283

284

polymeric materials (Sangeetha et al. 2011). Selecting new bacterial strains or improving bacterial strains is a prerequisite and effective solution in industrial applications and will be important for maximal lipase production. Pseudomonas species are well known for their ability to produce and secrete a large number of useful extracellular enzymes. Cloning the novel lipase gene with distinct features, especially from easily grown bacterium, is of interest for industrial applications. Although many lipases from Pseudomonas sp. have been intensively investigated (Gupta et al. 2004), there was no reports of lipase gene expression coding from Pseudomonas synxantha. In this work, the novel recombinant enzyme LipPS1 with detailed enzymatic properties and biodegradation of waste grease had preferable research significance.

Protein sequence alignment showed that LipPS1 belongs to lipase family I.3. Homology analysis revealed that LipPS1 in Pseudomonas synxantha shared the 50-90\% identity with predicted triacylglycerol lipase in Pseudomonas sp.. The homology results reveal the remarkable research significance of the novel recombinant enzyme including enzyme characterizations. The LipPS1 was stable at pH 6.0-10.0 compared with that of Pseudomonas aeruginosa SL-72 (pH 7.0-8.0) (Verma et al. 2012), Pseudomonas fluorescens ( $\mathrm{pH}$ 7.0) (Panizza et al. 2013), Pseudomonas cepacia (pH 7.0) (Li et al. 2015) Pseudomonas gessardii (pH 5.0) (Ramani et al. 2010) and Pseudomonas stutzeri PS59 (pH 8.5) (Li et al. 2014). The optimum temperature (40 $\left.{ }^{\circ} \mathrm{C}\right)$ of the recombinant lipase is similar to lipase from $P$. gessardii, $P$. fluorescens, $P$. fragi and $P$. mendoncina, which were found to be optimally active within $35-45^{\circ} \mathrm{C}$ (Ramani and Sekaran 2012).

In this study, various metal ions $\left(\mathrm{Ca}^{2+}, \mathrm{Fe}^{2+}, \mathrm{Mg}^{2+}, \mathrm{Cu}^{2+}, \mathrm{Mn}^{2+}, \mathrm{Co}^{2+}, \mathrm{Ni}^{2+}\right.$ and $\left.\mathrm{Zn}^{2+}\right)$ were used to test the influences on the enzyme activity. All the tested metal ions $(1 \mathrm{mM})$ were found to inhibit the enzyme activity except $\mathrm{Mg}^{2+}$. However, among the reported lipases, the influences of the metal ions on enzyme activities are quite different. Many lipases were stimulated by metal ions like $\mathrm{Ca}^{2+}$, such as Pseudomonas aeruginosa lipase (1 mM, 116\%) (Benattouche 2012), Bacillus cereus C7 lipase (1 mM, $\left.200 \%\right)$ (Dutta and Ray 2009) and Bacillus subtilis lipase (10 mM, 116\%) (Ma et al. 2006). On the other hand, the activity of Bacillus pumilus lipase B26 $\left(\mathrm{Ca}^{2+}\right.$-independent lipase) was almost constant at a wide range of $\mathrm{Ca}^{2+}$ concentration (Kim et al. 2002). The protein structure that lipases do not contain calcium binding sites may provide the presence of this reason. $\log P$ is a measure of the polarity of an organic solvent, which is defined as the logarithm of its partition coefficient in a standard n-octane/water two phase 
305

306

307

308

system. Laane et al. (1987) concluded that the solvent parameter that correlates best with enzyme activity was $\log P$. In this study,

various solvents with different $\log P$ were used to test the enzyme stability (Table 1). The results indicated that LipPS1 was highly denatured in hydrophobic solvents such as Benzene or n-hexane but was fairly stable in alkanes and short chain (C1-C4) alcohols. LipPS1 revealed high hydrolysis activity of waste oils in aqueous phase as a result of its stability in aqueous solvent, Fats and oils are the major wastes generated from food processing industries, dairy industries, kitchen activities, bakeries and beverages industries etc. and are released into running water or sewages without prior treatment which causes destruction not just to the environment but also to the flora and fauna. Many lipases have been studied in various literature reports in relation to their biodegradation of fats and oils. A lipase produced by Penicillium chrysogenum SNP5 was employed for the bioremediation of used cooking oil (Kumar et al. 2012). Two lipases derived from Bacillus subtilis and Bacillus pumilus showed high biodegradability towards African locust bean oil (Ouoba et al. 2003). Aspergillus and Penicillium lipases are able to convert waste cooking olive oil into lipid-rich biomass (Papanikolaou et al. 2011), which could be used as an excellent food or feed nutritional supplement. To shorten lipase-catalyzed reaction time and reduce enzyme loss, a Recirculating Packed Bed Reactor was used for production of pinolenic acid concentrate from pine nut oil (Zhao et al. 2012). Even so, there was no reports of lipase from Pseudomonas synxantha lipase been studied. In this study, we found that the enzyme was considerable stable in short chain (C1-C4) hydrophilic alcohols. For Pseudomonas synxantha PS1 isolated from oil well produced water in Shengli oilfield, these may be the reasons of high conversion in biodegradation of waste grease.

\section{Acknowledgments}

This research was financially supported by the National High Technology Research and Development Program of China (No. 2013AA102109, NO. 2012AA022206), the Fundamental Research Funds for the Central Universities of China (No. WF1214047), the National Natural Science Foundation of China (No. C050203-31200596) and the National Major Science and Technology Projects of China (No. 2012ZX09304009). 
Angkawidjaja, C., You, D.-j. and Matsumur, H. 2007 Crystal structure of a family I.3 lipase from Pseudomonas sp. MIS38 in a closed conformation. Febs Lett 581, 5060-5064.

Benattouche, Z. 2012 Isolation, purification and properties of lipase from Pseudomonas aeruginosa. Afr J Biotechnol 11, 12415-12421.

Bose, A. and Keharia, H. 2013 Production, characterization and applications of organic solvent tolerant lipase by Pseudomonas aeruginosa AAU2. Biocatal Agr Biotechnol 2, 255-266.

Cai, X., Ma, J., Wei, D.Z., Lin, J.P. and Wei, W. 2014 Functional expression of a novel alkaline-adapted lipase of Bacillus amyloliquefaciens from stinky tofu brine and development of immobilized enzyme for biodiesel production. Anton Van Leeuwenhoek 106, 1049-1060.

Dhake, K.P., Karoyob, A.H. and Mohamed H. Mohamedc 2013 Enzymatic activity studies of Pseudomonas cepacia lipase adsorbed onto copolymer supports containing $\beta$-cyclodextrin. J Mol Catal B-enzym 87, 105-112.

Dutta, S. and Ray, L. 2009 Production and characterization of an alkaline thermostable crude lipase from an isolated strain of Bacillus cereus C7. Appl Biochem biotechnol 159, 142-154.

Fang, Y., Lu, Z., Lv, F., Bie, X., Liu, S., Ding, Z. and Xu, W. 2006 A newly isolated organic solvent tolerant Staphylococcus saprophyticus M36 produced organic solvent-stable lipase. Curr Microbiol 53, 510-515.

Grbavc ic, S., Markovic, D. and Rajilic'-Stojanovic, M. 2015 Development of an Environmentally Acceptable Detergent Formulation for Fatty Soils Based on the Lipase from the Indigenous Extremophile Pseudomonas aeruginosa Strain. J Surfact Deterg 18, 383-395.

Gupta, R., Gupta, N. and Rathi, P. 2004 Bacterial lipases: an overview of production, purification and biochemical properties. Appl Microbiol Biotechnol 64, 763-781.

Hakiminia, F., Ranjbar, B., Khalifeh, K. and Khajeh, K. 2013 Kinetic and thermodynamic properties of Pseudomonas fluorescence lipase upon addition of proline. Int J Biol Macromol 55, 123-126.

Joshi, G.K., Kumar, S., Tripathi, B.N. and Sharma, V. 2006 Production of alkaline lipase by Corynebacterium paurometabolum, MTCC 6841 isolated from Lake Naukuchiatal, Uttaranchal State, India. Curr Microbiol 52, 354-358.

Kim, H.K., Choi, H.J., Kim, M.H., Sohn, C.B. and Oh, T.K. 2002 Expression and characterization of Ca ${ }^{2+}$-independent lipase from Bacillus pumilus B26. Biochim Biophys Acta 1583, 205-212.

Kulkarni, N. and Gadre, R.V. 2002 Production and properties of an alkaline, thermophilic lipase from Pseudomonas fluorescens NS2W. J Ind Microbiol Biot 28, 344-348.

Kumar, S., Mathur, A., Singh, V., Nandy, S., Khare, S.K. and Negi, S. 2012 Bioremediation of waste cooking oil using a novel lipase produced by Penicillium chrysogenum SNP5 grown in solid medium containing waste grease. Biores Technol 120, 300-304.

Lee, J.H., Ashby, R.D., Needleman, D.S., Lee, K.T. and Solaiman, D.K.Y. 2012 Cloning, sequencing, and characterization of lipase genes from a polyhydroxyalkanoate (PHA)-synthesizing Pseudomonas resinovorans. Appl Microbiol Biot 96, 993-1005.

Li, J., Yue, L., Li, C., Pan, Y. and Yang, L. 2015 Enantioselectivity and catalysis improvements of Pseudomonas cepacia lipase with Tyr and Asp modification. Catal Sci Technol 5, 2681-2687.

Li, X.-L., Zhang, W.-H., Wang, Y.-D., Dai, Y.-J., Zhang, H.-T., Wang, Y., Wang, H.-K. and Lu, F.-P. 2014 A high-detergent-performance, cold-adapted lipase from Pseudomonas stutzeri PS59 suitable for detergent formulation. J Mol Catal B-enzym 102, 16-24.

Lotti, M., Brocca, S. and Porro, D. 2001 High lipase production by Candida rugosa is associated with G1 cells. A flow cytometry study. Biotechnol Lett 23, 1803-1808.

Luna, C., Verdugo, C. and Sancho, E.D. 2014 Production of a biodiesel-like biofuel without glycerol generation, by using Novozym 435, an immobilized Candida antarctica lipase. Biores Bioprocess 1, 1-13. 
Ma, J., Zhang, Z., Wang, B., Kong, X., Wang, Y., Cao, S. and Yan, F. 2006 Overexpression and characterization of a lipase from Bacillus subtilis. Protein Expres Purif 45, 22-29.

Maraite, A., Hoyos, P., Carballeira, J.D., Cabrera, Á.C., Ansorge-Schumacher, M.B. and Alcántara, A.R. 2013 Lipase from Pseudomonas stutzeri: Purification, homology modelling and rational explanation of the substrate binding mode. J Mol Catal B-enzym 87, 88-98.

Ouoba, L.I.I., Cantor, M.D., Diawara, B., Traoré, A.S. and Jakobsen, M. 2003 Degradation of African locust bean oil by Bacillus subtilis and Bacillus pumilus isolated from soumbala, a fermented African locust bean condiment. J Appl Microbiol 95, 868-873.

Pahoja, V.M. and Sethar, M.A. 2002 A review of enzymatic properties of lipase in plants, animals and microorganisms. Pak J Appl Sci 2, 474-484.

Panizza, P., Syfantou, N., Pastor, F.I., Rodriguez, S. and Diaz, P. 2013 Acidic lipase Lip I.3 from a Pseudomonas fluorescens-like strain displays unusual properties and shows activity on secondary alcohols. J Appl Microbiol 114, 722-732.

Papanikolaou, S., Dimou, A., Fakas, S., Diamantopoulou, P., Philippoussis, A., Galiotou-Panayotou, M. and Aggelis, G. 2011 Biotechnological conversion of waste cooking olive oil into lipid-rich biomass using Aspergillus and Penicillium strains. J Appl Microbiol 110, 1138-1150.

Peng, R., Lin, J. and Wei, D. 2010 Purification and characterization of an organic solvent-tolerant lipase from Pseudomonas aeruginosa CS-2. Appl Biochem Biotechnol 162, 733-743.

Rajendran, A. and Thangavelu, V. 2007 Optimization of medium composition for lipase production by Candida rugosa NCIM 3462 using response surface methodology. Can J Microbiol 53, 643-655.

Ramani, K., John Kennedy, L., Ramakrishnan, M. and Sekaran, G. 2010 Purification, characterization and application of acidic lipase from Pseudomonas gessardii using beef tallow as a substrate for fats and oil hydrolysis. Pross Biochem 45, 1683-1691.

Ramani, K. and Sekaran, G. 2012 Production of lipase from Pseudomonas gessardii using blood tissue lipid and thereof for the hydrolysis of blood cholesterol and triglycerides and lysis of red blood cells. Bioproc Biosyst Eng 35, 885-896.

Sangeetha, R., Arulpandi, I. and Geetha, A. 2011 Bacterial Lipases as Potential Industrial Biocatalysts: An Overview. Res J Microbiol 6, 1-24.

Tan, T., Lu, J., Nie, K., Deng, L. and Wang, F. 2010 Biodiesel production with immobilized lipase: A review. Biotechnol Adv 28, 628-634.

Verma, S., Saxena, J., Prasanna, R., Sharma, V. and Nain, L. 2012 Medium optimization for a novel crude-oil degrading lipase from Pseudomonas aeruginosa SL-72 using statistical approaches for bioremediation of crude-oil. Biocatal Agr Biotechnol 1, 321-329.

Zhao, T., Kim, B.H., Hong, S.I., Yoon, S.W., Kim, C.T., Kim, Y. and Kim, I.H. 2012 Lipase-catalyzed production of pinolenic acid concentrate from pine nut oil using a recirculating packed bed reactor. J Food Sci 77, C267-C271. 
Table 1 Effect of various organic solvents (Methanol, Ethanol, Acetonitrile, N-butyl alcohol, Are propanol, n-hexane, Isopropanol, DMSO, Acetone and Benzene) (15\% (v/v) and 25\% (v/v)) on the recombinant lipase activity. The enzyme activity was measured using the spectrophotometric assay as above at $40^{\circ} \mathrm{C}(\mathrm{pH} 8.0)$.

\begin{tabular}{|c|c|c|}
\hline \multirow[t]{2}{*}{ Organic solvent } & \multicolumn{2}{|c|}{ Relative activity (\%) } \\
\hline & $15 \%$ & $25 \%$ \\
\hline Control & 100 & 100 \\
\hline Methanol & 112 & 87 \\
\hline Ethanol & 127 & 88 \\
\hline Acetonitrile & 95 & 78 \\
\hline N-butyl alcohol & 116 & 69 \\
\hline Are propanol & 96 & 50 \\
\hline n-hexane & 83 & 74 \\
\hline Isopropanol & 95 & 61 \\
\hline DMSO & 93 & 85 \\
\hline Acetone & 92 & 88 \\
\hline Benzene & 63 & 46 \\
\hline
\end{tabular}

The data represent the mean of three experimental repeats with SD of $\leq 5 \%$. 
Table 2 Effect of metal ions on the lipase activity was determined with various metal ions (2 and $10 \mathrm{mM})$ such as $\mathrm{Ca}^{2+}, \mathrm{Fe}^{2+}, \mathrm{Mg}^{2+}, \mathrm{Cu}^{2+}, \mathrm{Mn}^{2+}, \mathrm{Co}^{2+}, \mathrm{Ni}^{2+}$ and $\mathrm{Zn}^{2+}(\mathrm{pH}$ 8.0). The reaction condition without metal ions was as control.

\begin{tabular}{|c|c|c|}
\hline \multirow[t]{2}{*}{ Metal ions } & \multicolumn{2}{|c|}{ Relative activity (\%) } \\
\hline & $2 \mathrm{mM}$ & $10 \mathrm{mM}$ \\
\hline Control & 100 & 100 \\
\hline $\mathrm{Ca}^{2+}$ & 92 & 62 \\
\hline $\mathrm{Fe}^{2+}$ & 80 & 53 \\
\hline $\mathrm{Mg}^{2+}$ & 110 & 106 \\
\hline $\mathrm{Cu}^{2+}$ & 87 & 35 \\
\hline $\mathrm{Mn}^{2+}$ & 90 & 13 \\
\hline $\mathrm{Co}^{2+}$ & 67 & 24 \\
\hline $\mathrm{Ni}^{2+}$ & 97 & 31 \\
\hline $\mathrm{Zn}^{2+}$ & 83 & 28 \\
\hline
\end{tabular}

The data represent the mean of three experimental repeats with SD of $\leq 5 \%$. 
Legends to Figures

Fig. 1 (a) Rooted phylogenetic tree of isolate PS1 to other Pseudomonas species. Phylogenetic tree was constructed based on comparison of $16 \mathrm{~S}$ rDNA sequences. Bootstrap values obtained with 1000 repetitions were indicated as percentages at all branches. (b) Transparent circle of wild bacteria on the screening plate. (c) Phenotype info of Pseudomonas synxantha PS1. (d) Degenerate primers design.

Fig. 2 (a) Lipase production by Pseudomonas synxantha using various carbon sources $\left(4 \mathrm{~g} \mathrm{l}^{-1}\right)$ and nitrogen sources $\left(8 \mathrm{~g} \mathrm{l}^{-1}\right)$ in the medium. (b) Lipase production of Pseudomonas synxantha obtained in different grease

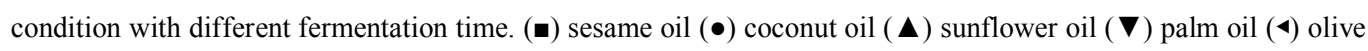
oil.

Fig. 3 Protein structure of LipPS1. (a) Conserved sequence alignment of LipPS1. The structures are denoted as follows: $\boldsymbol{\Lambda}$, the catalytic site (Ser207, Asp255 and His313). The reserved amino acid motif GXSXG is boxed. (b) Phylogenetic tree based on the protein sequences of LipPS1 and relating species. Bootstrap values obtained with 1000 repetitions were indicated as percentages at all branches. (c) The three-dimensional structure of this enzyme was predicted by the SWISS-MODEL server. (d) The catalytic triad $\mathrm{Ser}^{207}$, $\mathrm{Asp}^{255}$, and $\mathrm{His}^{313}$ residues were seen in the regions (in green).

Fig. 4 Recombinant lipase analysis. (a) SDS-PAGE analysis of the recombinant lipase and purified protein with an induction temperature of $20 \mathrm{oC}$ and an induction time of $18 \mathrm{~h}$. lane $\mathrm{M}$ : standard marker proteins; lane 1: supernatant of recombinant bacteria lysate. $\left(20^{\circ} \mathrm{C}\right)$; lane 2: supernatant of empty pET28a lysate; lane 3: purified recombinant protein. (b) Transparent circle of recombinant bacteria on the testing plate. (c) Relative activity on different substrates.

Fig. 5 Characterization of LipPS1. (a) The pH optimum of the recombinant lipase activity was studied over a range from $\mathrm{pH}$ 2-10 for $5 \mathrm{~min}\left(40^{\circ} \mathrm{C}\right)$. The following buffer systems were used: $\mathrm{pH}$ 4-5 with $100 \mathrm{mM}$ citric acid-sodium 
citrate, pH 6-7 with $200 \mathrm{mM}$ sodium phosphate, pH 8.0 with $50 \mathrm{mM}$ Tris-HCl, 9-10 with $50 \mathrm{mM}$ glycine-NaOH.

(b) The $\mathrm{pH}$ stability of the recombinant lipase activity was determined by incubating the enzyme in different buffers for $12 \mathrm{~h}$ and incubated at $40^{\circ} \mathrm{C}$. (c) The temperature optimum for the enzyme activity was assayed at $10-60^{\circ} \mathrm{C}(\mathrm{pH} 8.0)$. (d) The thermal stability of LipPS1 was evaluated by assaying its residual activity after incubation of the enzyme at various temperatures for $12 \mathrm{~h}$ in sodium phosphate buffer $(\mathrm{pH} \mathrm{8.0)}$.

Fig. 6 Biodegradation of LipPS1. (a) Phenomenon of biodegradation of waste oil. (b) Yield of fatty acid from waste oil biodegradation at various temperatures with different time. $(\boldsymbol{\bullet}) 20^{\circ} \mathrm{C}(\boldsymbol{\Delta}) 30^{\circ} \mathrm{C}(\boldsymbol{\nabla}) 40^{\circ} \mathrm{C}(\triangleleft) 50^{\circ} \mathrm{C}$. 
(a)

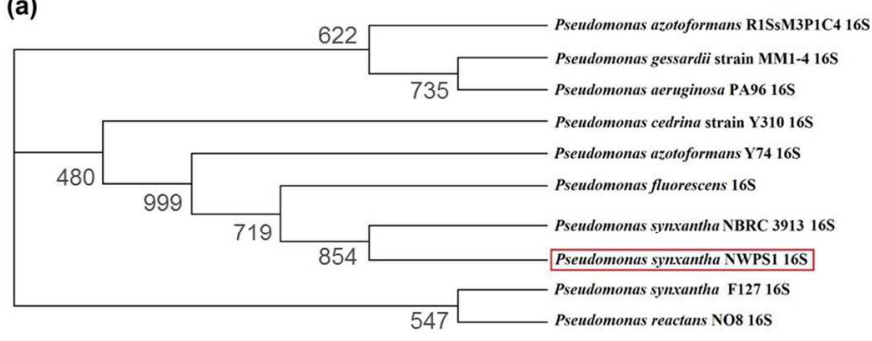

(b)

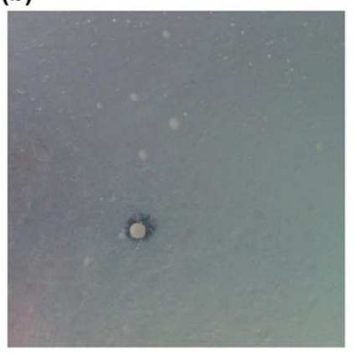

(c)

(d)

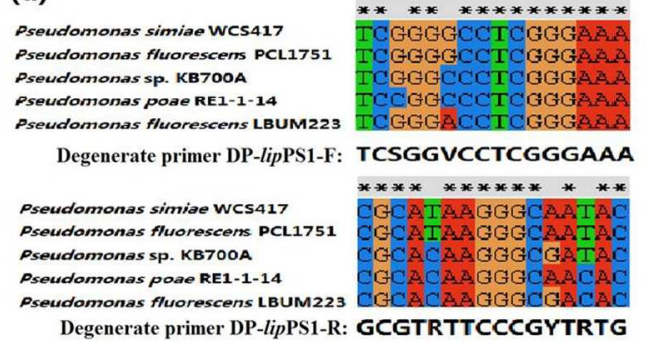

Fig. 1 (a) Rooted phylogenetic tree of isolate PS1 to other Pseudomonas species. Phylogenetic tree was constructed based on comparison of 16S rDNA sequences. Bootstrap values obtained with 1000 repetitions were indicated as percentages at all branches. (b) Transparent circle of wild bacteria on the screening plate. (c) Phenotype info of Pseudomonas synxantha PS1. (d) Degenerate primers design. $235 \times 137 \mathrm{~mm}(150 \times 150 \mathrm{DPI})$ 
(a)

\begin{tabular}{llll}
\hline Carbon sources & $\begin{array}{l}\text { Lipase activity } \\
(\mathrm{U} / \mathrm{ml})\end{array}$ & Nitrogen sources & $\begin{array}{l}\text { Lipase activity } \\
(\mathrm{U} / \mathrm{ml})\end{array}$ \\
\hline Lactose & $6.53 \pm 0.32$ & Casein & $3.47 \pm 0.65$ \\
Maltose & $5.65 \pm 0.26$ & Tryptone & $7.8 \pm 0.52$ \\
Starch & $1.32 \pm 0.47$ & Yeast extract & $2.57 \pm 0.29$ \\
Sucrose & $4.71 \pm 0.65$ & soybean flour & $5.83 \pm 0.78$ \\
& & Peanut powder & $5.64 \pm 0.60$ \\
\hline
\end{tabular}

(b)

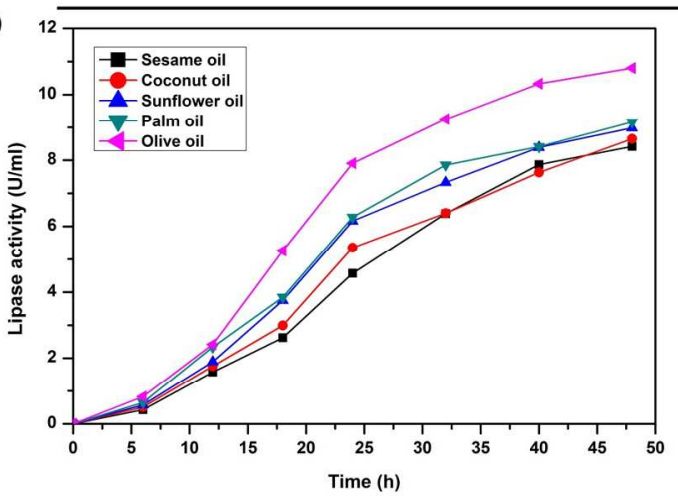

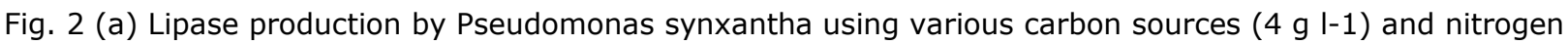
sources $(8 \mathrm{~g} \mathrm{l}-1)$ in the medium. (b) Lipase production of Pseudomonas synxantha obtained in different grease condition with different fermentation time. ( $)$ sesame oil $(\bullet$ ) coconut oil $(\boldsymbol{\Delta})$ sunflower oil $(\boldsymbol{\nabla})$ palm oil (4) olive oil.

$227 \times 160 \mathrm{~mm}(220 \times 220$ DPI $)$ 
(a)
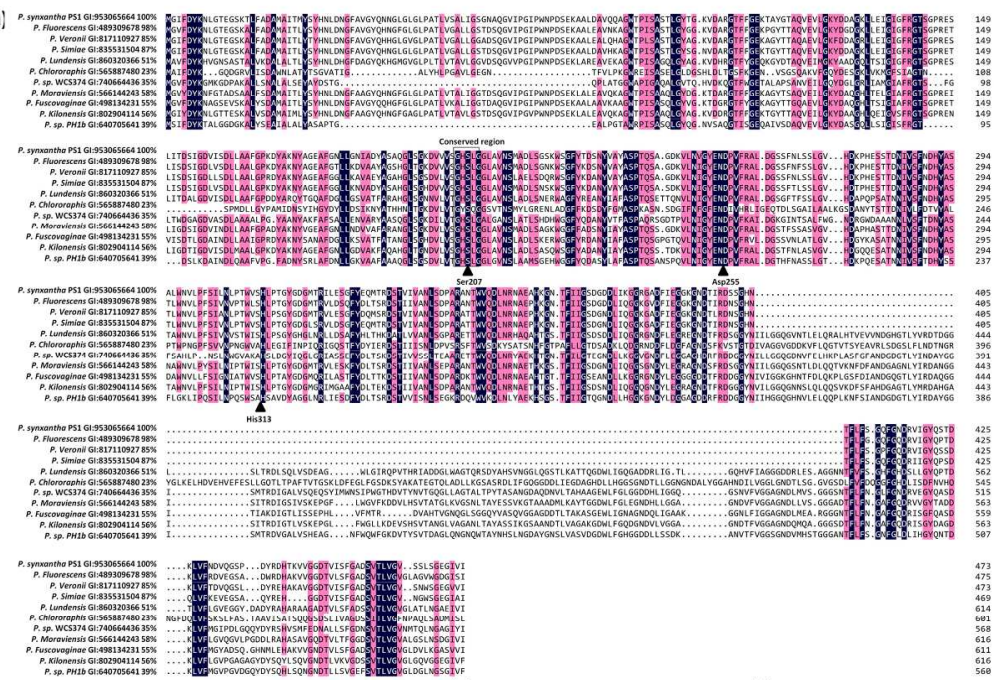

(b)
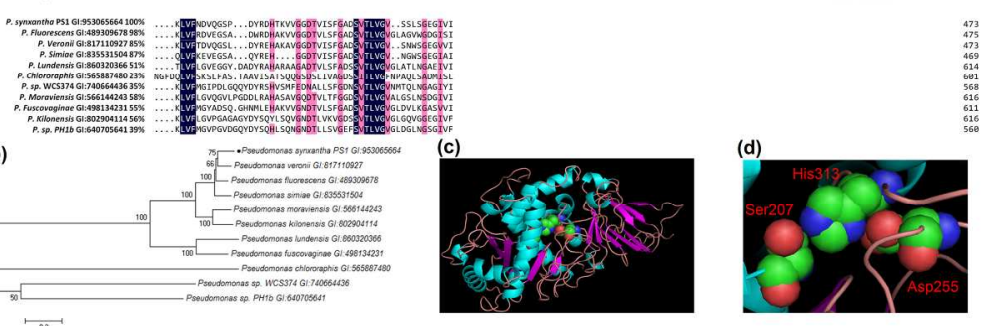

Fig. 3 Protein structure of LipPS1. (a) Conserved sequence alignment of LipPS1. The structures are denoted as follows: $\mathbf{\Lambda}$, the catalytic site (Ser207, Asp255 and His313). The reserved amino acid motif GXSXG is boxed. (b) Phylogenetic tree based on the protein sequences of LipPS1 and relating species. Bootstrap values obtained with 1000 repetitions were indicated as percentages at all branches. (c) The threedimensional structure of this enzyme was predicted by the SWISS-MODEL server. (d) The catalytic triad Ser207, Asp255, and His313 residues were seen in the regions (in green).

$201 \times 140 \mathrm{~mm}(300 \times 300$ DPI $)$ 

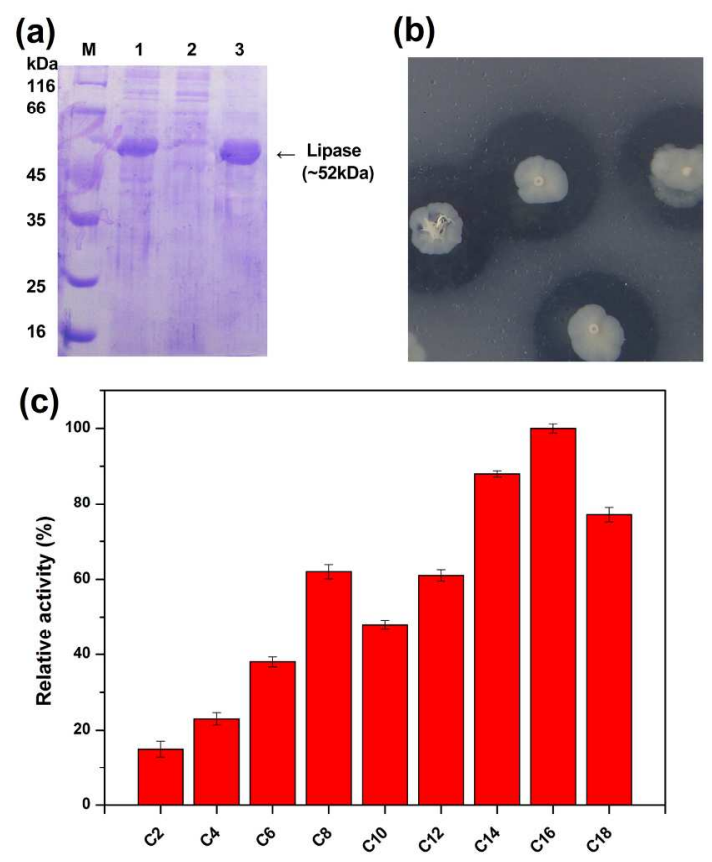

Fig. 4 Recombinant lipase analysis. (a) SDS-PAGE analysis of the recombinant lipase and purified protein with an induction temperature of $20 \mathrm{oC}$ and an induction time of $18 \mathrm{~h}$. lane $\mathrm{M}$ : standard marker proteins; lane 1 : supernatant of recombinant bacteria lysate. $\left(20^{\circ} \mathrm{C}\right)$; lane 2 : supernatant of empty pET28a lysate; lane 3: purified recombinant protein. (b) Transparent circle of recombinant bacteria on the testing plate. (c) Relative activity on different substrates.

$$
203 \times 142 \mathrm{~mm}(300 \times 300 \mathrm{DPI})
$$


(a)

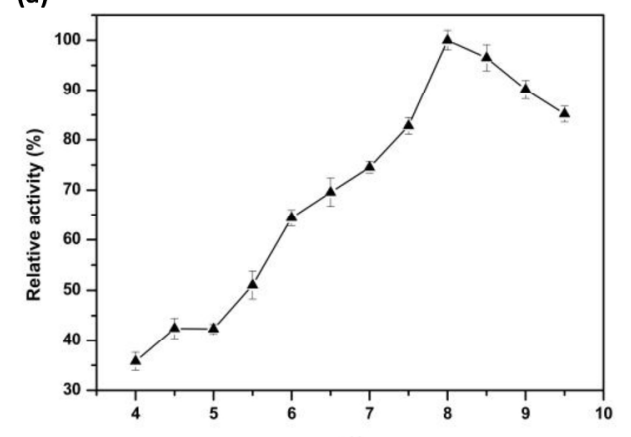

(c)

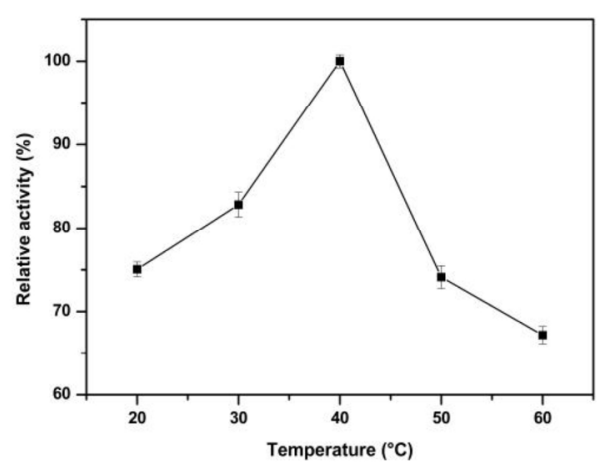

(b)

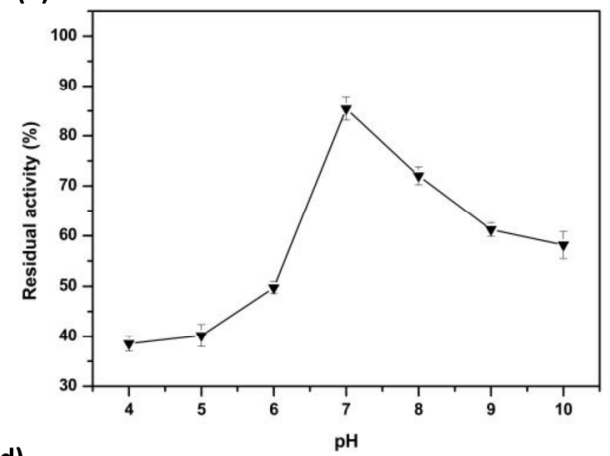

(d)

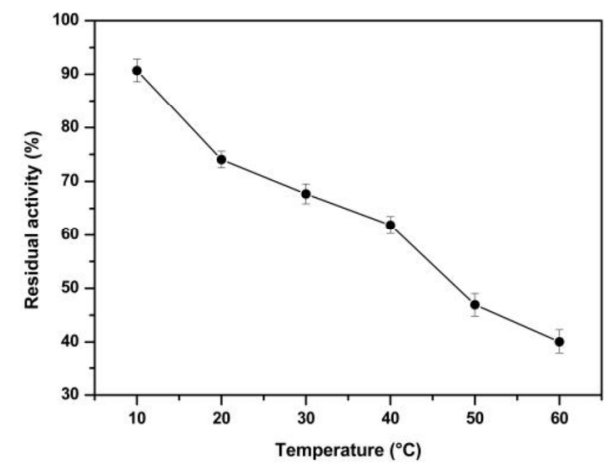

Fig. 5 Characterization of LipPS1. (a) The $\mathrm{pH}$ optimum of the recombinant lipase activity was studied over a range from $\mathrm{pH} 2-10$ for $5 \mathrm{~min}\left(40^{\circ} \mathrm{C}\right)$. The following buffer systems were used: $\mathrm{pH} 4-5$ with $100 \mathrm{mM}$ citric acid-sodium citrate, $\mathrm{pH}$ 6-7 with $200 \mathrm{mM}$ sodium phosphate, $\mathrm{pH} 8.0$ with $50 \mathrm{mM}$ Tris- $\mathrm{HCl}$, 9-10 with 50 mM glycine- $\mathrm{NaOH}$. (b) The $\mathrm{pH}$ stability of the recombinant lipase activity was determined by incubating the enzyme in different buffers for $12 \mathrm{~h}$ and incubated at $40^{\circ} \mathrm{C}$. (c) The temperature optimum for the enzyme activity was assayed at $10-60^{\circ} \mathrm{C}(\mathrm{pH} 8.0)$. (d) The thermal stability of LipPS1 was evaluated by assaying its residual activity after incubation of the enzyme at various temperatures for $12 \mathrm{~h}$ in sodium phosphate buffer $(\mathrm{pH} 8.0)$.

$106 \times 80 \mathrm{~mm}(600 \times 600 \mathrm{DPI})$ 
(a)
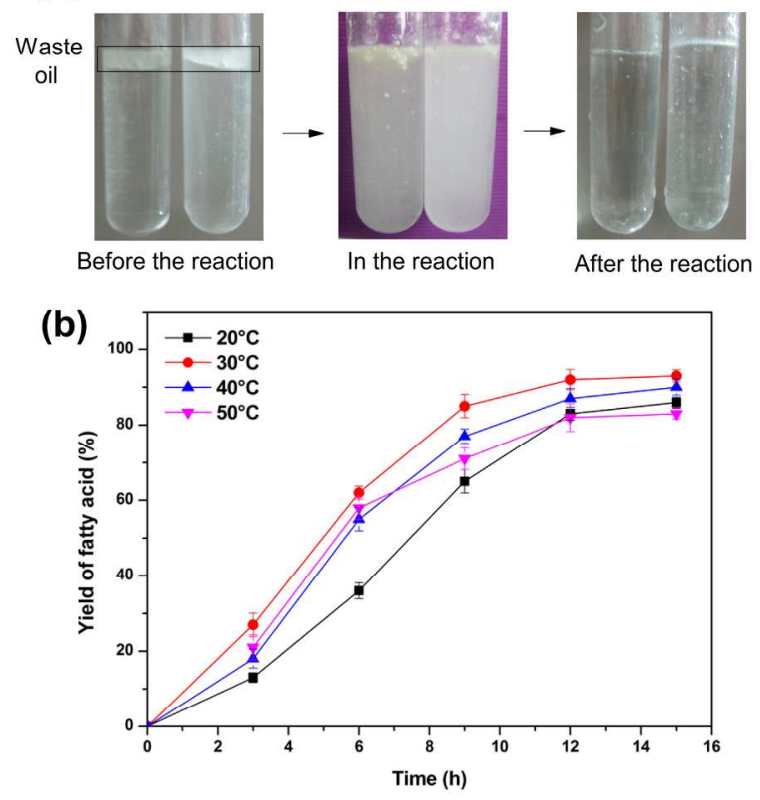

Fig. 6 Biodegradation of LipPS1. (a) Phenomenon of biodegradation of waste oil. (b) Yield of fatty acid from waste oil biodegradation at various temperatures with different time. $(\boldsymbol{\nabla}) 20^{\circ} \mathrm{C}(\boldsymbol{\Delta}) 30^{\circ} \mathrm{C}(\boldsymbol{\nabla}) 40^{\circ} \mathrm{C}(\triangleleft) 50^{\circ} \mathrm{C}$. $203 \times 142 \mathrm{~mm}(300 \times 300$ DPI) 